\section{Delayed diagnosis in angiokeratoma corporis diffusum (Anderson-Fabry's disease)}

Angiokeratoma corporis diffusum is a rare $\mathrm{X}$-linked disorder caused by a deficiency of the enzyme $x$-galactosidase within the cellular lysosomes. ${ }^{1}$ The circulating and urinary levels of the glycolipid ceramidetrihexoside are increased, causing gradual deposition of the abnormal lipid in the small vessels throughout the body. ${ }^{2}$

\section{Clinical features}

Pains in the fingers and toes beginning in late childhood are a major feature of the disorder. These are frequently transient but often excruciating. The cardinal sign is a cutaneous eruption consisting of tiny, painless, angiomatous punctae, confined mainly to the lower half of the body, although occasionally found within the mouth. Clusters occur over both trochanters and around the umbilicus, to which they impart a characteristic rosette appearance. Rare in women, the eruption in men may be concealed by the underpants. Corneal opacities, retinal vein abnormalities, and disturbances of temperature regulation are common, and renal failure or intracrania haemorrhages are the usual terminal events. ${ }^{3}$ Diagnosis based on biochemical assay alone is rare. ${ }^{4}$ We describe here three cases.

\section{Case 1}

At the age of 9 this patient was seen by a paediatrician for pains in the terminal finger joints and intermittent episodes of mild fever. All routine investigations were normal and a second opinion excluded any deficiency state as a cause of his diminutive stature. At 19 years investigations by a physician with an interest in arthritic conditions disclosed no abnormality. Domestic disharmony was noted and the development of similar symptoms in a younger brother (case 2) seemed to support the suggestion of a psychological disturbance. Diazepam was prescribed. At 24 years his distress was pronounced and dermatological advice was sought about the significance of a facial eruption and angiomatous flecks on the trunk.

Examination disclosed slightness of stature, elfin features, facial rosacea and tiny angiomatous lesions concentrated over both hips and around the umbilical rim. The blood pressure was $160 / 100 \mathrm{~mm} \mathrm{Hg}$ and the optic fundal veins were slightly tortuous. The electrocardiogram and chest radiograph were normal but the leucocyte $\alpha$-galactosidase levels were low (see table).

Leucocyte enzyme levels

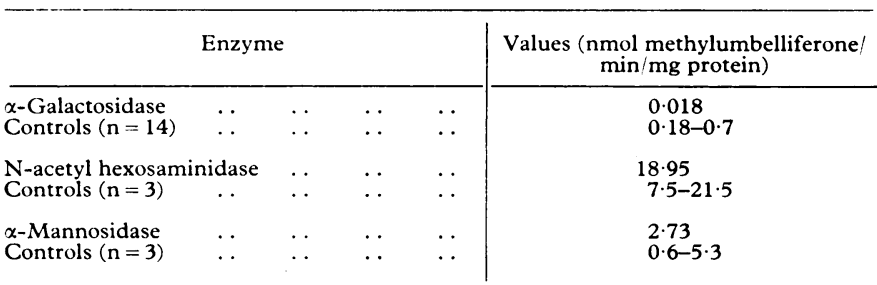

Conversion: SI to traditional units-Methylumbelliferone: $1 \mathrm{nmol} \approx 176 \mathrm{ng} / 1$.

\section{Case 2}

This patient, brother of the first, was 15 years old at the time of examination. His pain was less severe. He had attended many times for chronic bronchitis, strabismus, and chronic otitis media, which had left him deaf to conversational tones. The deafness, slight mental backwardness, a low pain threshold, and a jocular disposition all militated against an early diagnosis. Moreover, he was normotensive and had no cutaneous eruption. He had bilateral corneal opacities and grossly distorted retinal vessels, however. The electrocardiograph was normal, and as in case 1 the renal function was unimpaired.

\section{Case 3}

This patient, a cousin of the other two, was attending yet another doctor for hypertension. Maternal consent for full examination or investigation was withheld. The skin displayed the characteristic stigmata of the disorder, however.

\section{Comment}

Clinical diagnosis of this disorder eluded the endeavours of four skilful and experienced practitioners of general medicine. Furthermore, the third patient was investigated for jaundice in the medical department of a teaching hospital, where his characteristic eruption passed without comment.

Recent advances in replacement treatment have increased the need for early recognition of this disorder, ${ }^{15}$ and, as little has been written about symptomatic support of these patients, wider discussion in the general medical press should facilitate detection and stimulate research. This is particularly the case with regard to the management of pain, about which relatively little has been written. We found that our patients benefited from carbamazepine in low doses.

We thank Dr H J Wallace for his suggestions in clinical management and encouragement to report our cases; Dr S Povey, Human Biochemical Unit, Medical Research Council, for measuring enzyme levels in case 1 ; and Miss $\mathrm{S}$ McKie for typing the manuscript.

${ }^{1}$ Brady, R, et al, New England fournal of Medicine, 1973, 289, 9.

2 Ferrans, V J, Hibbs, R G, and Buda, C D, American fournal of Cardiology, 1969, 24, 95.

${ }^{3}$ Wise, D, Wallace, $\mathrm{H} \mathrm{J}$, and Jellinek, E H, Quarterly fournal of Medicine, $1962,31,177$.

4 Urbain, G, Phillipart, M, and Peremans, J, Archives of Internal Medicine, 1969, 24, 72.

${ }^{5}$ Clarke, J T, et al, New England fournal of Medicine, 1972, 28, 1215.

(Accepted 24 September 1976)

Cumberland Infirmary, Carlisle

P C MITCHELL, FRCP ED, Colonel, RAMC (retd), formerly consultant dermatologist

A TAAFFE, MRCP, registrar in dermatology (now locum senior registrar in dermatology, University Hospital of Wales, Cardiff)

\section{Hyponatraemia during carbamazepine treatment}

Since the discovery in 1966 that the anticonvulsant carbamazepine has antidiuretic activity, ${ }^{1}$ there has been only one report of water intoxication attributed to this drug. ${ }^{2}$ The finding of hyponatraemia in an epileptic patient receiving carbamazepine led us to conduct a prospective study of the frequency of electrolyte imbalance in a group of carbamazepine recipients attending a neurology clinic. We present here the preliminary results.

\section{Patients, methods, and results}

Sixteen patients attending the neurology clinic of Glasgow Royal Infirmary were reviewed. Their average age was $37 \cdot 1 \pm \mathrm{SE}$ of mean $4 \cdot 2$ years, the average daily dose of carbamazepine $690 \pm 81 \mathrm{mg}$, and the duration of treatment $22.4 \pm 5.5$ months. All were taking carbamazepine for epilepsy (14 patients) or trigeminal neuralgia (2 patients). Six patients were receiving the drug alone and the others were taking it with other anticonvulsants.

Details of patients on carbamazepine

\begin{tabular}{|c|c|c|c|c|c|c|c|c|}
\hline \multirow{2}{*}{$\begin{array}{l}\text { Case } \\
\text { No }\end{array}$} & \multirow{2}{*}{$\begin{array}{c}\text { Age } \\
\text { (years) }\end{array}$} & \multirow{2}{*}{ Sex } & \multicolumn{2}{|c|}{$\begin{array}{c}\text { Carbamazepine } \\
\text { treatment }\end{array}$} & \multirow{2}{*}{$\underset{(\mu \mathrm{mol} / \mathrm{l})}{\text { Cpss }}$} & \multirow{2}{*}{$\begin{array}{c}\text { Plasma } \\
\text { sodium } \\
(\mathrm{mmol} / \mathrm{l})\end{array}$} & \multirow{2}{*}{$\begin{array}{c}\text { Plasma } \\
\text { osmolality } \\
(\mathrm{mmol} / \mathrm{kg})\end{array}$} & \multirow{2}{*}{$\begin{array}{l}\text { Other } \\
\text { drugs }\end{array}$} \\
\hline & & & $\begin{array}{l}\text { Duration } \\
\text { (months) }\end{array}$ & $\begin{array}{l}\text { Daily } \\
\text { dose } \\
\text { (mg) }\end{array}$ & & & & \\
\hline $\begin{array}{r}1 \\
2 \\
3 \\
4 \\
5 \\
6 \\
7 \\
8 \\
9 \\
10 \\
11 \\
12 \\
13 \\
14 \\
15 \\
16\end{array}$ & $\begin{array}{l}60 \\
60 \\
29 \\
65 \\
30 \\
17 \\
28 \\
68 \\
27 \\
14 \\
34 \\
32 \\
27 \\
34 \\
39 \\
30\end{array}$ & $\begin{array}{l}M \\
F \\
F \\
F \\
F \\
F \\
F \\
F \\
M \\
F \\
M \\
F \\
M \\
F \\
M \\
M\end{array}$ & $\begin{array}{r}60 \\
60 \\
60 \\
1 \\
5 \\
36 \\
4 \\
21 \\
11 \\
36 \\
4 \\
24 \\
22 \\
2 \\
11 \\
2\end{array}$ & $\begin{array}{r}1400 \\
1200 \\
1000 \\
800 \\
800 \\
800 \\
800 \\
750 \\
600 \\
600 \\
600 \\
400 \\
400 \\
300 \\
300 \\
300\end{array}$ & $\begin{array}{l}70 \\
29 \\
42 \\
40 \\
36 \\
39 \\
44 \\
29 \\
31 \\
22 \\
24 \\
25 \\
23 \\
16 \\
21 \\
18\end{array}$ & $\begin{array}{l}130 \\
136 \\
124 \\
126 \\
130 \\
133 \\
135 \\
142 \\
135 \\
135 \\
138 \\
136 \\
137 \\
137 \\
138 \\
141\end{array}$ & $\begin{array}{l}256 \\
271 \\
250 \\
251 \\
256 \\
270 \\
277 \\
300 \\
278 \\
280 \\
281 \\
294 \\
287 \\
283 \\
280 \\
295\end{array}$ & $\begin{array}{l}\mathbf{P} \\
\mathbf{S} \\
\mathrm{P} \\
\mathbf{P} \\
\mathrm{V} \\
\mathrm{V} \\
\mathbf{P r} \\
\mathbf{P} \\
\mathbf{P b} \\
\mathrm{V}\end{array}$ \\
\hline
\end{tabular}

Cpss = Carbamazepine steady-state concentration. $\mathbf{P}=$ Phenytoin. $\mathbf{S}=$ Salbutamol $=$ Valproic acid. $\mathrm{Pr}=$ Primidone. $\mathrm{Pb}=$ Phenobarbitone.

Conversion. SI to traditional thits-Cpss: $1 \mu \mathrm{mol} / 1 \approx 0 \cdot 24 \mu \mathrm{g} / \mathrm{ml}$. Plasma sodium 